\title{
Tomographic Pallet Device
}

National Cancer Institute

\section{Source}

National Cancer Institute. Tomographic Pallet Device. NCI Thesaurus. Code C50294.

The part of a tomography machine on which the subject lays. 